\title{
NOWA LOGIKA UNII EUROPEJSKIEJ W OBSZARZE WSPARCIA FINANSOWEGO POLEPSZANIA INNOWACYJNOŚCI MALYCH I ŚREDNICH PRZEDSIĘBIORSTW
}

\begin{abstract}
Streszczenie
W artykule zaprezentowano nowe podejście do finansowania innowacyjności sektora małych i średnich przedsiębiorstw w nowej perspektywie finansowania Unii Europejskiej. W celu omówienia założeń nowej perspektywy finansowej Unii Europejskiej, przedstawiono implikacje funkcjonującego systemu wsparcia innowacyjności przedsiębiorstw w perspektywie 2007-2013. Na tej podstawie wskazano niedomagania istniejącego systemu wsparcia innowacyjności MŚP. Zaprezentowano również założenia dotyczące polityki wsparcia innowacyjności w nowym okresie programowania. W rozważaniach odniesiono się w szczególności do planowanych instrumentów finansowego wspierania innowacyjności MŚP.
\end{abstract}

Słowa kluczowe: rozwój lokalny, innowacyjność, instrumenty finansowe

\section{NEW APPROACH OF EU TO FINANCIAL SUPPORT FOR INNOVATION IN SMALL AND MEDIUM-SIZED ENTERPRISES}

\section{Summary}

The paper presents a new approach to financing innovation in small and medium-sized enterprises in the new EU budgetary perspective. In order to discuss the objectives of the new financial perspective of the EU, the author discusses the implications of the functioning support innovation system, taking into account the years 2007-2013. On this basis, the deficiencies of the existing system are indicated. Also presented are the assumptions of innovation support policy in the new programming period. The discussion specifically addresses the financial instruments to support innovative SMEs.

Key words: local development, innovation, financial instruments

\section{Wstęp}

Innowacje są ważnym czynnikiem pobudzającym rozwój każdej gospodarki. Decydują o poziomie oraz kierunku rozwoju współczesnego przedsiębiorstwa, oznaczając: postęp, rozwój i przewagę konkurencyjną.

${ }^{1}$ Prof. dr hab. Beata Zofia Filipiak - Wydział Nauk Ekonomicznych i Zarządzania, Uniwersytet Szczeciński; e-mail: bfilipiak@wneiz.pl. 
Wspieranie innowacyjności staje się jednym z ważniejszych celów polityki państwa zarówno na poziomie kraju, poszczególnych województw (regionów), jak i na poziomie lokalnym. Działanie to jest odzwierciedleniem priorytetów Unii Europejskiej, jej polityki w minionej dekadzie, jak i staje się niezwykle ważnym priorytetem w nowym okresie programowania Unii Europejskiej. Stąd w licznych opracowaniach nie tylko wskazuje się bariery innowacyjności, które napotykają przedsiębiorstwa, a w szczególności sektor małych i średnich przedsiębiorstw (MŚP), ale również wykazywany jest fakt, że istniejący system wsparcia innowacyjności jest mało efektywny, a instrumenty finansowego wsparcia nie odgrywają roli stymulatorów procesów innowacyjnych.

Celem artykułu jest ukazanie problemów związanych z wykorzystaniem środków Unii Europejskiej jako ważnego elementu wsparcia innowacyjności MŚP oraz na tej podstawie ocena nowej logiki wsparcia innowacyjności z wykorzystaniem instrumentów finansowych przez przedsiębiorstwa sektora MŚP w nowej perspektywie programowania.

\section{Implikacje funkcjonującego systemu wsparcia innowacyjności przedsię- biorstw w unijnej perspektywie finansowania 2007-2013}

W literaturze przedmiotu zwraca się uwagę na niską efektywność programów wsparcia innowacyjności sektora MŚP tworzonych i oferowanych przez polski rząd oraz zależne od niego agencje i organizacje. Dostępne opracowania wskazuja, że programy pomocowe polskiego rządu są fragmentaryczne i oparte na wielostopniowym systemie ocen i podejmowania decyzji [Klonowski, 2009; Mazurek-Kucharska i in., 2008; Grabowski i in., 2003]. Oceny działań programów mających wspierać innowacyjność MŚP, wskazania dokumentu ewaluacyjnego, jak również przyjęte i ogłoszone w Dzienniku Urzędowym Unii Europejskiej L 347 z dnia 20 grudnia 2013 roku Rozporzadzenie Parlamentu Europejskiego $i$ Rady (UE) Nr 1287/2013 z dnia 11 grudnia 2013 roku ustanawriajace program na rzecz konkurencyjności przedsiębiorstw oraz matych i średnich przeedsiebiorstw (COSME) (2014-2020) pozwalają na stwierdzenie, że mimo pozytywnych efektów, istnieja niedomagania w zakresie wspierania innowacyjności sektora MŚP. Znaczące problemy dotyczyły i dotycza:

- dostępu MŚP do finansowania w formie instrumentów kapitałowych i dłużnych;

- dostępu do rynków, w szczególności unijnych, lecz także na poziomie globalnym;

- ramowych warunków konkurencyjności i trwałości przedsiębiorstw unijnych, głównie MŚP;

- $\quad$ krzewienia przedsiębiorczości i kultury przedsiębiorczości w MŚP.

Podstawowe instrumenty, pobudzające innowacyjność MŚP, obejmują przede wszystkim: bezzwrotne dotacje, pożyczki, gwarancje oraz fundusze podwyższonego ryzyka. Środki funduszy Unii Europejskiej w postaci programów operacyjnych, w tym „Innowacyjna Gospodarka” (PO IG), były przeznaczane zwłaszcza na inwestycje kapitałowe (38\%) oraz prowadzenie B+R (prawie 11\% wszystkich środków). Pozostałe $40 \%$ było dystrybuowane wśród różnych instytucji otoczenia biznesu (Krajowy System 
Usług, publiczne instytucje naukowo-badawcze). Dotacje na inwestycje kapitałowe, które w znacznej mierze wspierają zakup nowych technologii, maszyn i urządzeń, stanowia prawie $40 \%$ wszystkich dostępnych środków. Wsparcie na działalność badawczo-rozwojową $\mathrm{B}+\mathrm{R}$ w przedsiębiorstwach jest mniejsze i wynosi $12,4 \%$ budżetu PO IG, koncentrując się również na dotacjach. Działania te, jak już zauważono, nie były do końca efektywne, co potwierdziły zarówno badania, jak i ekspertyzy rządowe [Klonowski, 2009; Kapil i in., 2013].

W licznych ekspertyzach rządowych, które znalazły się u podstawy opracowania programów interwencji Unii Europejskiej, wskazuje się na realizację zasady selektywności, a najbardziej rozpowszechniona we współczesnej Europie polityką jest wsparcie innowacji przez politykę podatkową (ulgi podatkowe w przypadku wydatków na badania i rozwój) lub inne wsparcie przez wydatki publiczne. W Polsce i pozostałych, nowych krajach członkowskich Unii Europejskiej dobrą okazją do prowadzenia skutecznej polityki wsparcia innowacji jest program Innowacyjna Gospodarka, finansowany z budżetu Unii Europejskiej. Niestety, pogłębione analizy dowodza。 że jest źle realizowany i nie przyczynia się do istotnego podniesienia poziomu technologicznego polskich firm [Bukowski i in., 2012; Kapil i in., 2013]. Znaczącym problemem jest właśnie selektywność, która spowodowała wybiórczą interwencję, a ta, w ujęciu lokalnym, czy też regionalnym, nie przyniosła istotnych rezultatów, lecz w ujęciu konkretnego przedsiębiorcy osiagnnięto realny, wymierny efekt. Ulgi podatkowe w Polsce nie cieszą się popularnością w takim stopniu, aby wpłynęły na rozwój innowacyjności gospodarki².

Absorpcja technologii powinna nadal pobudzać rozwój kraju, jednak nie ulega wątpliwości, iż Polska będzie musiała zdecydowanie przesunąć punkt ciężkości w kierunku $\mathrm{B}+\mathrm{R}$ i tworzenia innowacyjnych produktów i usług. W minionej perspektywie dominowały dotacje bezzwrotne. W okresie 2007-2013 rola takich instrumentów wsparcia działalności $\mathrm{B}+\mathrm{R}$, jak: kredyty, kapitał podwyższonego ryzyka, prywatnych instrumentów kapitałowych, jak również ulg podatkowych w okresie 2007-2013 była znamiennie mniejsza.

W tabeli 1. zaprezentowano finansowy aspekt wykorzystania środków w okresie 2007-2013. Należy podkreślić, że wymiernymi efektami alokacji środków Unii Europejskiej na wzrost innowacyjności sa:

- $\quad$ nowe miejsca pracy;

- $\quad$ wpływ na kondycję gospodarczą regionu;

- pojawienie się etatów badawczych, służących innowacyjności i rozwojowi gospodarek lokalnych;

2 Może o tym świadczyć fakt, że zgodnie z danymi Ministerstwa Finansów, w roku 2012 skorzystało z ulgi tylko 42 przedsiębiorców opodatkowanych PIT, a łączna kwota ulg wyniosła jedynie 3333 zł i 94 przedsiębiorców rozliczających się z fiskusem na podstawie CIT, natomiast tutaj łączna kwota ulg wyniosła 4674 tys. zł. W 2011 roku skorzystało z ulgi 250 podatników PIT, na łączną kwotę 1048 zł oraz 97 podatników CIT na kwotę 2793 tys. zł. Ministerstwo Finansów oddało pod prace sejmowe projekt zmian w ustawie o podatku dochodowym od osób prawnych, który zakłada zmiany w zakresie ulgi na nowe technologie i wprowadzenie w jej miejsce kredytu na innowacje [Szymborska-Sutton, 2014; dokument elektroniczny, tryb dostępu: http://www.mf.gov.pl, data wejścia: 05.06.2014]. 
- $\quad$ pojawienie się i rozwój instrumentów inżynierii finansowej, stanowiących tzw. odnawialne źródła finansowania (pożyczki, poręczenia);

- $\quad$ rozwój przedsiębiorczości i innowacyjności przedsiębiorstw (rysunek 1.).

TABELA 1.

Alokacja środków Unii Europejskiej na PO IG w okresie 2007-2013 w Polsce

\begin{tabular}{|c|c|c|c|c|c|c|}
\hline \multirow{2}{*}{\multicolumn{2}{|c|}{ Wyszczególnienie }} & \multicolumn{2}{|c|}{$\begin{array}{c}\text { Wnioski o dofinanso- } \\
\text { wanie zatwierdzone do } \\
\text { realizacji przez Instytu- } \\
\text { cję Zarzadzającą (po } \\
\text { ocenie formalnej i me- } \\
\text { rytorycznej) }\end{array}$} & \multirow{2}{*}{$\begin{array}{c}\begin{array}{c}\text { Zawarte } \\
\text { umowy }\end{array} \\
\text { Liczba }\end{array}$} & \multicolumn{2}{|c|}{$\begin{array}{l}\text { Płatności dokonane na } \\
\text { rzecz beneficjentów }\end{array}$} \\
\hline & & Liczba & $\begin{array}{l}\text { Wartość dofi- } \\
\text { nansowania }\end{array}$ & & $\begin{array}{l}\text { Wartość dofi- } \\
\text { nansowania }\end{array}$ & $\begin{array}{c}\% \text { wyko- } \\
\text { rzystania } \\
\text { środków } \\
\text { publicz- } \\
\text { nych } \\
\end{array}$ \\
\hline Prorytet/ Oś & $\begin{array}{l}\text { Alokacja w PLN } \\
\text { (dane na podsta- } \\
\text { wie Arkusza Kal- } \\
\text { kulacyjnego MF) } \\
\end{array}$ & 1 & 2 & 3 & 4 & 5 \\
\hline Ogółem & 42524435708,71 & 18295 & 48336135439,18 & 16124 & 24509280767,52 & $57,64 \%$ \\
\hline $\begin{array}{l}\text { Oś priorytetowa } 1 . \\
\text { Badania i rozwój nowo- } \\
\text { czesnych technologii }\end{array}$ & 6346433782,36 & 1613 & 7277407326,03 & 1385 & 4199951074,03 & $66,18 \%$ \\
\hline $\begin{array}{l}\text { Oś priorytetowa } 2 \text {. } \\
\text { Infrastruktura sfery } B+R\end{array}$ & 6007152983,62 & 152 & 6221293357,30 & 149 & 3815880573,96 & $63,52 \%$ \\
\hline $\begin{array}{l}\text { Oś priorytetowa } 3 . \\
\text { Kapitat dla innowacji }\end{array}$ & 1315296148,73 & 416 & 1709923048,43 & 316 & 962711938,22 & $73,19 \%$ \\
\hline $\begin{array}{l}\text { Oś priorytetetowa } 4 . \\
\text { Inwestycje w innowacyjne } \\
\text { przedsiew ziecia }\end{array}$ & 15466110989,38 & 2349 & 18898852408,14 & 2029 & 8679773778,22 & $56,12 \%$ \\
\hline $\begin{array}{l}\text { Oś priorytetowa } 5 . \\
\text { Dyfurja innowacji }\end{array}$ & 1857369023,27 & 663 & 1605077949,67 & 589 & 1119075512,04 & $60,25 \%$ \\
\hline $\begin{array}{l}\text { Priorytet } 6 . \\
\text { Polska gospodarka na } \\
\text { rynku międsynarodonym }\end{array}$ & 1719434381,09 & 5263 & 1783144028,00 & 4441 & 912615242,94 & $53,08 \%$ \\
\hline $\begin{array}{l}\text { Oś priorytetowa } 7 . \\
\text { Spoteczeństwo informacyjne } \\
\text { - budowa elektronicznej } \\
\text { administracji }\end{array}$ & 3935060133,56 & 43 & 4380030985,54 & 37 & 2107674526,59 & $53,56 \%$ \\
\hline $\begin{array}{l}\text { Priorytet 8. Spoteczeństwo } \\
\text { informacyjne - zwiekszenie } \\
\text { innowacyjności gospodarki }\end{array}$ & 5009780563,71 & 7585 & 5631164324,72 & 6974 & 2201482 261,71 & $43,94 \%$ \\
\hline $\begin{array}{l}\text { Oś priorytetowa } 9 \text {. } \\
\text { Pomoc techniczna }\end{array}$ & 867797702,99 & 211 & 829242011,35 & 204 & 510115859,81 & $58,78 \%$ \\
\hline
\end{tabular}

Źródło: opracowanie własne na podstawie danych Ministerstwa Gospodarki, dokument elektroniczny, tryb dostępu: [https://www.poig.gov.pl, data wejścia: 05.06.2014].

Z zaprezentowanych danych wynika znacząca alokacja środków Unii Europejskiej w projekty, które są wspierane przez PO IG, dedykowany innowacyjności polskiej gospodarki, w tym przedsiębiorstw. Przeciętne wykorzystanie środków zbliża się do $60 \%$, co jest podyktowane jeszcze trwającą realizacja projektów, ale także ewaluacją i sytuacjami związanymi z niewykorzystaniem środków, czy też dokonanymi zwrotami. Jednocześ- 
nie należy zwrócić uwagę na znaczące kwoty wsparcia inwestycji (inwestycje w: infrastrukturę, innowacje i kapitał ludzki) i sfery B+R.

\section{Struktura wsparcia finansowego innowacji}

\section{RYSUNEK 1.}

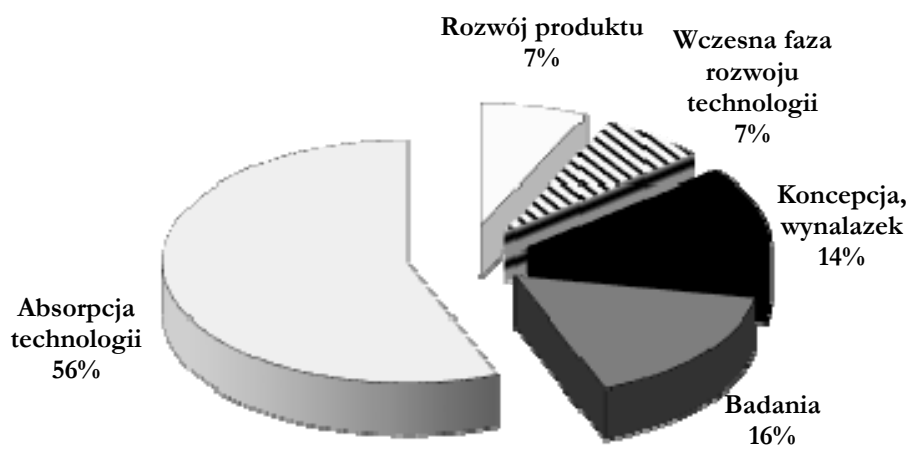

Źródło: opracowanie własne na podstawie: [Innovation Diagnostics in Poland, 2011].

Niezaprzeczalnym faktem jest osiagnięcie wymiernego efektu w stosunku do przedsiębiorstw korzystających ze wsparcia. Udzielone wsparcie kreuje rozwój, który umożliwia umocnienie pozycji przedsiębiorstwa na rynku. Mimo tego efektu jednostkowego, wsparcie przez swoją selektywność nie wpływa w sposób zrównoważony, a jedynie powoduje skokowy rozwój regionu. Dzięki niemu rozwijają się wyłącznie wybrane przedsiębiorstwa, stąd wspomniana wada - selektywność.

\section{Wyzwania związane z wdrożeniem nowej logiki interwencji Unii Europejskiej w latach 2014-2020}

Analiza przyjętych dokumentów rządowych wskazuje, że wsparcie finansowe zwiazzane z podwyższaniem innowacyjności będzie skierowane głównie na wzrost innowacyjności przedsiębiorstw [Program Rozwoju..., 2014, s. 5 i 10]. Rząd przyjął szereg programów, wytycznych, jak również podjął współpracę międzynarodowa, służącą właśnie poprawie przedsiębiorczości i innowacyjności gospodarki, w tym MŚP. Świadczyć o tym mogą takie działania, jak:

- polityki: innowacyjności, przedsiębiorczości i nowej szansy;

- dokument pod nazwą „Wizja zrównoważonego rozwoju dla polskiego biznesu 2050";

- Strategia Innowacyjności i Efektywności Gospodarki „Dynamiczna Polska 2020" (SIEG), której zadaniem jest tworzenie wysoce konkurencyjnej gospodarki w wyniku podjęcia działań mających na celu dostosowanie otoczenia 
regulacyjnego i finansowego do potrzeb innowacyjnej i efektywnej gospodarki czy stymulowania innowacyjności przez wzrost: efektywności wiedzy i pracy, efektywności wykorzystania zasobów naturalnych i surowców, umiędzynarodowienia polskiej gospodarki;

- $\quad$ realizacja założeń foresightu technologicznego przemysłu w Polsce, którego nadrzędnym celem jest nie tylko identyfikacja kluczowych technologii oraz obszarów przemysłowych o znaczeniu strategicznym dla polskiego przemysłu, lecz także rozwijanie kluczowych obszarów przemysłu;

- przyjęcie dokumentu „Krajowe inteligentne specjalizacje” i priorytetów gospodarczych w obszarze $\mathrm{B}+\mathrm{R}+\mathrm{I}$, których rozwój zapewni: tworzenie innowacyjnych rozwiązań społeczno-gospodarczych, zwiększenie wartości dodanej gospodarki i podniesienie jej konkurencyjności na rynkach zagranicznych;

- uczestnictwo i rozwijanie „Programu ramowego na rzecz konkurencyjności przedsiębiorstw oraz Małych i Średnich Przedsiębiorstw (COSME)”.

$Z$ analizy systemu wdrażania instrumentów finansowanych ze środków strukturalnych i budżetowych wynika, iż poszczególne instytucje centralne w kilku przypadkach posiadają te same zadania oraz podobne instrumenty w kontekście wspierania innowacyjności i finansowania projektów badawczo-rozwojowych przedsiębiorstw. Konieczna jest zmiana. Przede wszystkim zmieni się rola takich instytucji, jak Agencji Rozwoju Przemysłu, Polskiej Agencji Rozwoju Przemysłu, NCBiR (problemy, które występowały to: dublowanie systemów zarządzania, nadzoru, baz danych, problemy z komunikacją między instytucjami, brak przejrzystości systemu wsparcia dla potencjalnych beneficjentów $)^{3}$.

Zmianie uległa również logika interwencji. Wsparcie rozwoju przedsiębiorstw będzie skoncentrowane w obszarach wskazanych w SIEG. Zakłada się, że dzięki wzrostowi innowacyjności dojdzie do poprawy pozycji konkurencyjnej przedsiębiorstw działających w Polsce, pozwalając na ich szybki rozwój, bardziej efektywne zaspokajanie potrzeb klientów oraz skuteczną odpowiedź na wyzwania konkurencji globalnej [Program Rozwoju..., 2014, s. 6-8].

Proponowany system wsparcia będzie polegać na udzielaniu dotacji głównie projektom obarczonym wysokim stopniem ryzyka. Instytucje zaangażowane w projektowanie, wdrażanie i monitorowanie systemu wsparcia powinny dążý do sytuacji, która umożliwi finansowanie większej liczby ryzykownych projektów. W Polsce przedsiębiorstwa nadal powinny móc korzystać $\mathrm{z}$ pomocy państwa $\mathrm{w}$ istotnych $\mathrm{z}$ gospodarczego punktu widzenia obszarach, w których nie działają mechanizmy rynkowe (szczególnie na ryzykownych rynkowo etapach procesu innowacji). Wsparcie to powinno pomóc im w szybszym rozwoju i skutecznym stawianiu czoła zagranicznym konkurentom [Program Rožwoju..., 2014, s. 24].

Wsparciu udzielanemu przez państwo musi towarzyszyć wkład własny przedsiębiorcy (to jest kontynuacja przyjętych wcześniej założeń). Ze względu na konieczność zapewnienia racjonalnego planowania i wydawania środków przez przedsiębiorcę, pomoc

\footnotetext{
${ }^{3}$ Szerzej na temat projektowanych zmian: [Program Rozpooju..., 2014, s. 46-48].
} 
publiczna będzie mieć charakter dofinansowania. To podejście ma zachęcać przedsiębiorców do podejmowania ryzyka (tu występuje nowa optyka). Nowe podejście zakłada jednoczesne, obok pomocy publicznej, stymulowanie rozwoju prywatnych źródeł finansowania projektów wysokiego ryzyka (założenia wsparcia zostaną przedstawione poniżej).

Zmienia się również zasada interwencji dotycząca wykorzystania poszczególnych rodzajów instrumentów. Za pomocą instrumentów zwrotnych będzie finansowany przede wszystkim zakup nowych technologii, maszyn i urządzeń (ryzyko biznesowe związane $\mathrm{z}$ wdrożeniem). W systemie grantowym pozostanie wspieranie zakupu technologii obarczonych dużym ryzykiem technologicznym (np. zakupionych jedynie w postaci know-bow w przypadku pierwszego wdrożenia w skali światowej), [Program Rožwoju..., 2014, s. 32-33, 46-49].

Wadą systemu w latach 2007-2013 był brak jednoznacznych kryteriów oceny projektów innowacyjnych. Zauważa się, że słabością tego okresu był popytowy charakter absorpcji środków Unii Europejskiej, z zasady krótkoterminowy, nastawiony na bieżące rozwiązywanie problemów. Stąd też procedury oraz kryteria nie odzwierciedlały $\mathrm{w}$ pełni potrzeby kreowania nowych wartości w postaci $\mathrm{B}+\mathrm{R}$ [Konkurencyjna Polska..., 2013, s. 132]. Należy przyjąć z zadowoleniem założenia dotyczące opracowania i wdrożenia kryteriów oceny projektów, które umożliwią ich kompleksową ocenę. Innowacyjne przedsiębiorstwa, zwłaszcza małe i średnie, miały problemy z pozyskaniem inwestorów, gdyż bez kompleksowego podejścia do projektów, w tym oceny zaangażowania, doświadczenia i zdolności osób prowadzących firmę, nie mogły liczyć na wsparcie finansowe. Nowa logika interwencji nie tylko ma na celu eliminację wskazanego niedomagania systemowego, ale dodatkowo wyznacza nowe reguły. Postuluje wyważenie kosztów i korzyści wynikających ze stopnia skomplikowania systemu oceny i monitorowania projektów. Szczególnie zmierza do tego, aby był to system maksymalnie uproszczony, a procedury uległy skróceniu i stały się przyjazne przedsiębiorcom (zwłaszcza MŚP).

Nowa logika interwencji wskazuje na skuteczność zapewnienia wsparcia. Powinno ono być monitorowane, a wnioski powinny oddziaływać wprost na decyzje dotyczące polityki gospodarczej oraz samych instrumentów. W minionym okresie programowania liczne publikacje i raporty przedstawiały problemy pomiaru, niedostosowanie mierników do realizowanych programów, czy też błędy w konstrukcji mierników.

Ewaluacja instrumentów wsparcia finansowego staje się jednym $z$ najważniejszych elementów systemowych w nowej logice interwencji. W związku z tym wybór instrumentów dokonywania ewaluacji, ich odpowiedniość do założonych celów, dobór metod ewaluacji i wskaźników winien zagwarantować właściwą ocenę stopnia osiagania celów i szybkość zmian w obowiązującej polityce i programach [Program Rozwoju..., 2014, s. 49-50].

Kolejnym postulatem, zmieniającym podejście do wykorzystania środków w nowej perspektywie, jest usprawnienie systemu obsługi przedsiębiorcy. W celu zapewnienia odpowiedniego systemu obsługi przedsiębiorcy na poziomie operacyjnym, a tym samym umożliwienia lepszego reagowania systemu na problemy beneficjentów, uzasadnione wydaje się stworzenie kompleksowego systemu informacji na temat wsparcia rozwoju przedsiębiorstw. MŚP wskazuja jako jedną z podstawowych barier dostępu do wsparcia 
finansowego, a więc w swoim rozwoju, brak informacji (kompleksowej i czytelnej). Należy możliwie szeroko zastosować automatyczny, interaktywny, elektroniczny system rejestracji, wnioskowania, informacji i monitoringu. System online pozwoli na wielokrotne korzystanie z już wprowadzonych informacji o przedsiębiorcy, co wpłynie na sprawność obsługi przedsiębiorcy, np. w przypadku kolejnego ubiegania się o wsparcie [Program Rozwoju..., 2014, s. 51].

Nowy system przyjmuje założenie inteligentnej specjalizacji. Założenie to wynika z konieczności optymalnego wykorzystania zasobów (zrównoważony rozwój), jak i przedstawionej krytyki udzielania selektywnego wsparcia [Krajowa..., 2014]. Wskazuje się nie tylko w dokumentach rządowych, lecz przede wszystkich w dokumentach Unii Europejskiej, że silna koncentracja tematyczna wsparcia specjalizacji, stanowiących przewagi konkurencyjne kraju, przyczyni się do rozwoju opartego na skuteczności podejmowanych działań oraz wymiernych efektach społeczno-gospodarczych. Ponadto położenie nacisku na wsparcie specjalizacji krajowych i regionalnych powinno prowadzić do większej koncentracji i bardziej efektywnego wykorzystania środków unijnych, a także poprawić koordynację i synergię między inicjatywami podejmowanymi na szczeblu wspólnotowym, krajowym oraz regionalnym. Zgodnie z artykułem 16 rozdziału III Komunikatu Komisji Europejskiej COM (2011) 615: Państwa cztonkowskie koncentruja wsparcie, zgodnie z przepisami dotyczacymi poszczególnych fundus:y, na działaniach prizynoszacych najwiekszq wartość dodana w odniesieniu do realizacio unijnej strategii na rzecz inteligentnego, trwatego w:rostu gospodarczego sprajjajacego wtaczeniu spotecznemu, podejmujac uyzinania określone w zaleceniach dotyczacych poszcrególmych panstw prayjetych na podstawie art. 121 ust. 2 Traktatu oraz. w odpowiednich zaleceniach Rady przyjetych na podstawie art. 148 ust. 4 Traktatu, a takize biorac pod unvage potrzeby krajowe i regionalne [Komunikat Komisji Europejskiej $\operatorname{COM(2012)~615,~2006,~}$ s. 43].

Należy podkreślić, że zarówno wskazane bariery, jak i opracowane założenia nowej logiki interwencji w okresie 2014-2020 mają służyć zwiększeniu efektywności i skuteczności absorpcji środków Unii Europejskiej, jak również innowacyjności polskiej gospodarki. Najwięcej barier i ograniczeń na drodze do efektywnej absorpcji pozwalającej nie tylko na utrzymanie się na rynku, lecz kreowanie rozwoju i wzrostu innowacyjności, napotykały właśnie MŚP. Nowa logika interwencji dostrzega ten problem. Warto zauważyć, że właśnie w Polsce znaczenie sektora MŚP jest szczególne, gdyż obejmuje on 99,8\% ogółu działających na polskim rynku przedsiębiorstw ${ }^{4}$, tworzy miejsca pracy i to właśnie w nim wypracowywane jest blisko 71,8\% PKB [Raport o stanie..., 2013, s. 15].

\section{Instrumenty finansowe wspierania innowacyjności MŚP w nowej perspektywie finansowej}

Trzeba zaznaczyć, że wsparcie innowacyjności MŚP w nowej perspektywie będzie realizowane za pomoca różnych inicjatyw, a tym samym i instrumentów. Pro-

\footnotetext{
${ }^{4}$ Zob.: Dokument elektroniczny, tryb dostępu: [http://www.poig.gov.pl/2014_2020/Strony/Wsparcie_ dla_firm_w_latach_2014_2020_23012014.aspx, data wejścia: 08.07.2014].
} 
gram Operacyjny „Innowacyjna Gospodarka” zostanie zastapiony programem operacyjnym „Inteligentny rozwój”. Program ten obejmuje szereg działań i wymusza powstanie nowych instrumentów wspierających innowacyjność. Szczególny nacisk kładzie się na wzrost innowacyjności MŚP, a zwłaszcza kreowanie przez różnego rodzaju programy, inicjatywy i instrumenty:

- $\quad$ stymulujące współpracę nauki i biznesu;

- bezpośredniego wsparcia systemowego innowacyjności i przedsiębiorczości (na podstawie „Programu rozwoju przedsiębiorstw”);

- $\quad$ rozwoju innowacyjnego kapitału ludzkiego [Program Operacyjny..., 2014, s. 19].

Znaczna część obszarów wsparcia będzie dotyczyła projektów systemowych, sprzyjających promocji innowacyjności oraz internacjonalizacji jako źródła konkurencyjności gospodarki. Współpraca między przedsiębiorstwami, biznesem i nauką będzie odbywać się z wykorzystaniem nowych instrumentów. W latach 2014-2020 następcą 7 PR będzie program „Horyzont 2020”, a programu CIP - program „COSME”. „Horyzont 2020" wprowadzi atrakcyjne rozwiązania dla małych i średnich przedsiębiorstw, które będą obejmować:

- innowacje w MŚP - innowacyjne rozwiązania dla wyzwań społecznych i kluczowych technologii - 15\% całkowitego budżetu w tych zakresach będzie przeznaczone dla MŚP;

- dostęp do instrumentów finansowanych dla MŚP;

- budowanie potencjału badawczego MŚP - program „Eurostars” [Komunikat..., 2011, s. 11-12; Program Operacyjny..., 2014, s. 106-108].

Ważnym programem, którego skutki są dość pozytywnie oceniane przez MŚP, był „Program ramowy na rzecz konkurencyjności i innowacji” (CIP). Wsparcie z tego instrumentu udzielano w postaci gwarancji pośrednikowi finansowemu: bankowi, funduszowi leasingowemu, innej, wybranej w konkursie organizowanym przez Europejski Fundusz Inwestycyjny (EFI), instytucji finansowej. Program ten charakteryzował się korzystniejszymi warunkami finansowania. W okresie 2009-2011 około 2 tys. MŚP w Polsce uzyskało wsparcie przez udzielenie preferencyjnych pożyczek lub gwarancji, co stanowi zaledwie około 5\% zapotrzebowania polskich MŚP na preferencyjne finansowanie. Krajowe instytucje finansowe udzieliły w okresie 2009-2011 preferencyjnych pożyczek i gwarancji blisko 40 tys. MŚP. Następcą tej inicjatywy jest program „COSME”, który ma na celu poprawę dostępu MŚP do finansowania, co oznacza stworzenie nowych instrumentów finansowych, takich jak: instrumenty kapitałowe i dłużne, które w szczególności będą dostępne dla MŚP mających problem z niską zdolnością kredytowa; lepszy dostęp do rynków trzecich, a to wiąże się z rozwojem Sieci Enterprise EuropeNetwork, która będzie świadczyć usługi na rzecz internacjonalizacji MŚP na rynkach trzecich [Program Rozwoju..., 2014, s. 56].

Kolejnym instrumentem jest „Program rozwoju przedsiębiorstw” (PRP) [Program Rozwoju..., 2014]. Obejmuje on nie tylko szeroki katalog zaproponowanych instrumentów wsparcia innowacyjności, ale stanowi wzajemnie powiązany i spójny system, w którym wspiera się każdy etap powstawania $\mathrm{B}+\mathrm{R}+\mathrm{I}$ oraz przedsiębiorstwa na każdym etapie rozwoju. W programie w sposób przejrzysty zdefiniowano instrumenty dedykowane MŚP. W celu wsparcia MŚP wskazuje się na następujące instrumenty finansowe: 
- $\quad$ instrumenty grantowe na B+R;

- ulga podatkowa na B+R;

- $\quad$ fundusze kapitału podwyższonego ryzyka;

- ułatwianie inwestowania w MŚP (aniołowie biznesu);

- $\quad$ utworzenie systemu finansowych instrumentów zwrotnych, skierowanych na zakup nowoczesnych: technologii, maszyn oraz urządzeń;

- $\quad$ wsparcie projektów kluczowych z punktu widzenia polskiej gospodarki;

- inkubacja innowacyjnych przedsiębiorstw;

- $\quad$ wsparcie dla początkujących przedsiębiorców (start-up).

Instrumenty grantowe na $\mathrm{B}+\mathrm{R}$ będą konsekwencją zmiany w stosunku do zasad dotychczas wdrażanych programów. Granty będą przeznaczane na dofinansowania najbardziej ryzykownych faz projektów $\mathrm{B}+\mathrm{R}$ obejmujących: rozwój samego pomysłu $\mathrm{B}+\mathrm{R}$, prototyp, instalację pilotażowa, wdrożenie wyników własnego $\mathrm{B}+\mathrm{R} /$ własnej technologii. Zakup nowych technologii, maszyn i urządzeń będzie wspierany głównie za pomocą systemu instrumentów zwrotnych (pożyczek i gwarancji).

Ulga podatkowa na $\mathrm{B}+\mathrm{R}$ jest wynikiem analiz $\mathrm{i}$ wskazań, że istnienie zachęt podatkowych z tytułu prowadzenia prac badawczo-rozwojowych ma istotny wpływ na wzrost wydatków przedsiębiorstw na badania naukowe i prace badawczo-rozwojowe (choć w literaturze przedmiotu panuje pogląd, że nie zawsze ulgi podatkowe są wystarczająca zachęta do podjęcia prac B+R [Konkurencyjna Polskea..., 2013, s. 122]). W Polsce, mimo zapowiedzi MNiSW, nie wprowadzono mechanizmów wspierania innowacyjności dzięki ulgom podatkowym przez wspieranie prac B+R. W miejsce funkcjonującej ulgi na nabycie nowych technologii zostanie wprowadzona efektywna ulga podatkowa dla przedsiębiorców prowadzących prace $\mathrm{B}+\mathrm{R}$, która umożliwi dodatkowe odliczenie części kosztów kwalifikowanych, związanych z działalnością badawczo-rozwojowa, zaliczanych do kosztów uzyskania przychodów [Program Roźwoju..., 2014, s. 81-82].

Kluczowym kierunkiem interwencji w nowym okresie programowania będzie wsparcie dostępu przedsiębiorstw do kapitału na innowacje (venture capital, private equity, anioły biznesu, doradztwo w zakresie wykorzystania wskazanych instrumentów finansowych). Fundusze kapitału podwyższonego ryzyka venture capital/private equity (VC/PE) będą odgrywać szczególną rolę w finansowaniu innowacyjnych przedsiębiorstw, ponieważ akceptują one znacznie wyższy poziom ryzyka niż inne instytucje, zwłaszcza banki. Podstawowym narzędziem wspierania inwestycji technologicznych, których celem jest komercjalizacja wyników prac $\mathrm{B}+\mathrm{R}$, będą zwrotne instrumenty kapitałowe funduszy VC/PE. Wsparcie zostanie udzielane projektom o wysokim potencjale rynkowym, wyłanianym w procedurze właściwej dla inwestorów kapitałowych ze środków programów i przedsięwzięć zakładających partnerstwo podmiotów publicznych i funduszy VC. Pozostałe wsparcie będzie przeznaczone na inwestycje kapitałowe typu PE, za pośrednictwem Krajowego Funduszu Kapitałowego oraz instrumentów współfinansowanych przez tzw. aniołów biznesu, a także zwrotne finansowanie za pomoca poręczeń i gwarancji. Finansowane będą różne fazy, od inkubacji, po fazę ekspansji. Zmieni się jednocześnie wysokość limitów inwestycyjnych na projekt. Zatem dużą szansę w pozyskiwaniu wsparcia mogą mieć te przedsiębiorstwa, które startuja, maja innowacyjny 
pomysł, chcą rozwijać się, a główną barierą jest kapitał [Program Rožwoju..., 2014, s. 82-84].

Ułatwianie inwestowania w MŚP to kontynuacja działania 3.3. PO IG Tworzenie systemu ułatwiajacego inwestowanie w MŚP, ukierunkowanego na aktywizację rynku inwestorów prywatnych przez tworzenie dogodnych warunków inicjowania współpracy inwestorów z przedsiębiorcami poszukującymi środków finansowych na realizację innowacyjnych przedsięwzięć. Celem omawianego instrumentu jest z jednej strony wsparcie sektora MŚP w przygotowaniu do pozyskania zewnętrznych źródeł finansowania, z drugiej zaś wsparcie sieci inwestorów (w tym aniołów biznesu) i umożliwienie poznania korzyści i usług oferowanych przez takie sieci.

Utworzenie systemu finansowych instrumentów zwrotnych, skierowanych na zakup nowoczesnych: technologii, maszyn oraz urządzeń będzie opierać się na, dotychczas stosowanych, poręczeniach i gwarancjach. Należy podkreślić, że przeważająca część środków na rozwój przedsiębiorstw w Polsce była przeznaczona do tej pory na instrumenty bezzwrotne, które charakteryzują się niższą efektywnością wykorzystania wsparcia publicznego. Ocenia się, że 1 EUR dotacji obecnie generuje około 2 EUR inwestycji i jest wykorzystane tylko raz. Zgodnie z przeprowadzonymi badaniami, największa luka finansowa istnieje w przedziale 1-5 mln PLN w sektorze małych firm oraz powyżej $10 \mathrm{mln}$ PLN w sektorze średnich firm [Klonowski, 2009, s. 50; Mechanizmy inżyierii..., 2010, s. 38].

System finansowych instrumentów zwrotnych będzie skierowany do sektora MŚP, a w szczególności do podmiotów zainteresowanych podniesieniem stopnia innowacyjności swojej firmy, zwłaszcza do przedsiębiorstw, które nie mają środków, czy też możliwości uzyskania dostępu do zewnętrznego finansowania na wdrożenie nowoczesnych technologii (zakup: nowoczesnych maszyn i urządzeń, know-how, licencji). Podstawowym warunkiem jest utworzenie linii produkcyjnej, zmodernizowanych lub nowych, w odniesieniu do dotychczasowej działalności, produktów bądź usług, np. wprowadzenie nowego wzoru przemysłowego jest uznawane za dokonanie innowacji, natomiast zmiana opakowania towaru nie jest innowacją [Program Rozwoju..., 2014, s. 85-89]. W tabeli 2. zaprezentowano proponowany system instrumentów zwrotnych.

TABELA 2.

\section{Proponowany system instrumentów zwrotnych}

\begin{tabular}{|c|c|}
\hline \multicolumn{2}{|l|}{ Proponowany system instrumentów zwrotnych } \\
\hline Zakup nowej technologii/maszyn i urządzeń (innowacja w skali świata i kraju) & $\begin{array}{l}\text { Działalność obrotowa i inwesty- } \\
\text { cyjna (innowacja w skali firmy) }\end{array}$ \\
\hline Pożyczka/kredyt (ze środków publicznych) & \multirow[b]{2}{*}{$\begin{array}{c}\text { Finansowanie poprzez fundusze } \\
\text { pożyczkowe i poręczeniowe dzia- } \\
\text { łające w regionach }\end{array}$} \\
\hline $\begin{array}{l}\text { Pożyczka/kredyt preferencyjny } \\
\text { a) preferencyjne oprocentowanie } \\
\text { b) karencja }\end{array}$ & \\
\hline
\end{tabular}

Źródło: opracowanie własne na podstawie: [Program Rozwoju..., 2014, s. 87]. 
Założeniem owego systemu instrumentów zwrotnych jest zmiana istniejącej formuly ich działalności (przede wszystkim zmiana dotyczy instrumentów inżynierii finansowej). Proponuje się utrzymać formułę wsparcia funduszy pożyczkowo-poręczeniowych, zmieniając priorytet. Nowy program poręczeniowo-gwarancyjny powinien być ukierunkowany na wspieranie innowacji przez poręczenia i gwarancje spłaty kredytów inwestycyjnych oraz kredytów obrotowych, powiązanych $z$ inwestycjami MŚP. Proponuje się także, by użycie instrumentów finansowych połączyć z ryzykiem wynikającym z realizacji projektu. Zasadniczym elementem będzie system poręczeń i gwarancji portfelowych (w tym również re-poręczenia, re-gwarancje) oraz pożyczka/kredyt (wsparte ze środków publicznych). Od przedsiębiorców będzie zależeć, z jakiego instrumenty skorzystaja. Najbardziej preferencyjne produkty finansowe będą oferowane przedsiębiorcom realizującym bardziej ryzykowne projekty. System preferencji będzie polegać na wykorzystaniu obniżonego oprocentowania (dofinansowanie dla instytucji różnicy między oprocentowaniem oferowanym w systemie a oprocentowaniem rynkowym) oraz wprowadzeniu karencji od spłaty kredytu/pożyczek, która w konsekwencji nie będzie oznaczała dla przedsiębiorcy wzrostu realnych zobowiązań przy spłacie pożyczki/kredytu [Program Rozwoju..., 2014, s. 85-89].

Z punktu widzenia polskiej gospodarki wsparcie kluczowych projektów będzie opierać się na założeniu, że innowacyjne postawy dużych przedsiębiorców sa powiązane ze zjawiskiem dyfuzji innowacji i rozprzestrzenienia innowacyjności również na sektor MŚP. Dla beneficjentów będą dostępne bezzwrotne instrumenty dedykowane przedsiębiorstwom i grupom przedsiębiorstw realizujących innowacyjne inwestycje o znacznej skali, z którymi będzie związane istotne zaangażowanie w działalność badawczo-rozwojową. Właśnie w łączeniu sił podmiotów z sektora MŚP upatruje się potencjalną możliwość uzyskania wsparcia finansowego.

Inkubacja innowacyjnych przedsiębiorstw to kolejna kontynuacja działań podjętych w okresie 2007-2013, w ramach której powstała w Polsce infrastrukturalna baza dla działalności inkubacyjnej (działanie 3.1. PO IG Inicjowanie dzৃiałalności innowacyjnej). Mimo pozytywnych efektów, konieczne jest podjęcie i rozszerzenie działalności inkubatorów. Wsparcie winno mieć na celu poprawę komercjalizacji posiadanej przez przedsiębiorstwo wiedzy, wdrażania produktów i usług, zdobywania finansowania, czy też kwestii ochrony własności intelektualnej [Ośrodki innowacji..., 2010, s. 61, s. 64, s. 87-89]. Ponadto działalność inkubatorów musi być wzmocniona o element mentoringu i coachingu, co pozwoli młodym przedsiębiorcom na szybszy rozwój firmy. Przede wszystkim do finansowania przewidziano następujące działalności:

- wsparcie inkubatora dla początkującego, innowacyjnego przedsiębiorcy będzie wielowymiarowe: udostępnienie infrastruktury, doradztwo i mentoring $\mathrm{w}$ zakresie tworzenia i prowadzenia przedsiębiorstwa ( $\mathrm{w}$ tym w zakresie korzystania $z$ dostępnych instrumentów wsparcia, głównie finansowych), zasilenie finansowe, inne usługi niezbędne dla nowej firmy;

- $\quad$ przyznawanie grantów przed-zalążkowych (ang. pre-seed), tzw. grantów na pomysły, które będa finansować działalność przez sześć miesięcy; te małe granty o wielkości do 50000 EUR, (według kursu z dnia udzielenia pomocy) będa 
przeznaczane na działania przed założeniem firmy (biznes plan, studia wykonalności, wnioski patentowe itp.);

- $\quad$ w pierwszym roku działalności firmy wsparcie inkubatora w postaci inwestycji kapitałowej w nowo powstałe przedsiębiorstwo może mieć wysokość do 200000 EUR, (według kursu z dnia udzielenia pomocy, poniżej 50\% udziałów instytucji wspierającej powstawanie innowacyjnych przedsiębiorstw w spółce);

- $\quad$ firmy korzystajacce $z$ instrumentu uzyskają dodatkowe preferencje (np. punkty) $\mathrm{w}$ razie ubiegania się o inny rodzaj wsparcia; zapewni to większą synergię prowadzonych przez państwo działań;

- $\quad$ wsparcie na prace przygotowawcze, przeznaczone na uruchomienie i testowanie rozwiązania opartego na innowacyjnym pomyśle [Program Rožwoju..., 2014, s. 92-94].

Wsparcie dla początkujących przedsiębiorców (start-up) jest kolejnym, ważnym instrumentem, który ma służyć pozyskaniu kapitału na inwestycje i rozwój firm, które właśnie powstały. Będzie ono odbywać się przez następujące działania:

- $\quad$ system instrumentów zwrotnych i dotacyjnych (pożyczki i poręczenia);

- preferencyjnie oprocentowana pożyczka dla rozpoczynających działalność gospodarcza;

- $\quad$ program „Pierwszy biznes-wsparcie w starcie” - pomoc w tworzeniu nowych firm i nowych miejsc pracy, w formie preferencyjnych pożyczek dla absolwentów szkół i wyższych uczelni, a także studentów ostatniego roku studiów wyższych oraz od 2014 roku dla bezrobotnych posiadających pomysł na własny biznes;

- $\quad$ kontynuacja obecnego systemu kredytów z poręczeniem, przeznaczonych na zakładanie lub rozwijanie działalności małych firm, w którym poręczenie jest od razu zapewniane przez instytucję zewnętrzna;

- działania kierowane do osób fizycznych, planujących rozpoczęcie własnej działalności gospodarczej, które będą obejmować pomoc bezzwrotną (w formie dotacji) oraz pomoca zwrotną (w formie preferencyjnie oprocentowanych pożyczek z ewentualną możliwością ich restrukturyzacji lub umorzenia);

- utrzymanie działania polegającego na inicjowaniu działalności innowacyjnej, kierowanego do nowo powstałych przedsiębiorców oraz instytucji wspierajacych powstawanie nowych firm innowacyjnych w formie objęcia udziałów lub dotacji na inkubację;

- $\quad$ utrzymanie dotacji przyznawanej bezrobotnemu jednorazowo na podjęcie działalności gospodarczej, w tym na pokrycie kosztów pomocy prawnej, konsultacji i doradztwa związanego z podjęciem tej działalności;

- $\quad$ system usług informacyjno-doradczych.

Rozwój innowacyjności nie jest możliwy bez rozwoju kapitału społecznego. Szczególnego znaczenia nabiera zatem wsparcie innowacyjności kapitału ludzkiego w przedsiębiorstwach. Ten problem został uwypuklony przede wszystkim w programie EFS na nowy okres programowania. Przyjmuje się założenie, że przedsiębiorca będzie samodzielnie decydował o wyborze usługi rozwojowej, odpowiadającej jego potrzebom 
(np.: bon edukacyjny, refundacja kosztów). Położony zostanie także większy nacisk na diagnozę potrzeb rozwojowych czy większą dywersyfikację świadczonych usług (np.: doradztwo biznesowe, mentoring, optymalizacja procesów zarządzania itp.). Dodatkowo, w celu wsparcia rozwoju kapitału ludzkiego, w zakresie wsparcia bezpośredniego dla MŚP w ramach regionów, zostanie opracowany Podmiotowy System Finansowania oparty na podejściu popytowym. Będzie on oferować system bonowy lub refundacyjny.

Należy podkreślić, że zwłaszcza MŚP będą musiały nauczyć się stosować środki przeznaczone na rozwój i zwiększanie ich innowacyjności w dwojaki sposób. Pierwszy, bezpośredni, jako inwestycje, czy też promowanie zachowań innowacyjnych. Drugi to innowacje w kapitał ludzki i wykorzystanie informacji. Tu zmiana mentalności, podejścia, nowa wiedza bądź umiejętność wykorzystywania informacji może przynieść reorientacje działania na konkurencyjnym rynku i wykorzystanie innowacji jako szczególnego rodzaju kapitału stymulującego rozwój. MŚP potrzebują informacji, muszą nauczyć się efektywnie z niej korzystać, budować przewage dzięki informacji i dostępowi do niej. Ponadto MŚP muszą również sprostać wyzwaniu i nauczyć się korzystania ze wsparcia: ośrodków innowacji, ośrodków przedsiębiorczości i instytucji finansowych [Ośrodki..., 2012, s. 11]. Właśnie nowa logika interwencji wskazuje nie tylko na podwyższanie umiejętności przez MŚP pod względem wykorzystania informacji, ale budowania na jej podstawie innowacji przez dostęp i selektywne wykorzystanie informacji, wiedzy i wsparcia pochodzącego z otoczenia.

\section{Podsumowanie}

Nowy okres programowania kładzie szczególny nacisk na innowacyjność gospodarki. Gospodarki krajów członkowskich, po okresie kryzysu i spowolnienia gospodarczego, wymagają szybkiego dostosowania i zmian, które pozwolą nadążyć za szybko rozwijającymi się gospodarkami światowymi.

Założenia nowego okresu programowania starają się wyeliminować niedociągnięcia i problemy występujące w okresie 2007-2013 dotyczące poprawy alokacji środków. Warto zauważyć, że stanowią swoistego rodzaju nową logikę interwencji. Z jednej strony instrumenty mają stymulować innowacyjność, interweniować w sposób zapewniający spójność realizacji jednoznacznych celów na konkretnych obszarach, a z drugiej nakazują realne zachowania (pomiar efektów, stopień realizacji celów). Dotychczasowy system nie był tak restrykcyjny, nie wymuszał konkretnych efektów społecznie i gospodarczo użytecznych, akceptował osiaganie efektów selektywnych i jednostkowych.

Nowy okres programowania nie przynosi przełomowych zmian w zakresie instrumentów wspierania innowacyjności. Zmienia logikę ich zastosowania, tak aby wymusić zachowania bardziej skuteczne z punktu widzenia alokacji środków. Akcentuje zwłaszcza pobudzanie innowacyjności wśród sektora MŚP, ma na celu zwiększenie dostępu do kapitału, ale jednocześnie zmusza do innowacyjnych zachowań w tym obszarze. Zmienia się także logika inwestowania i wykorzystania kapitału.

Pytanie, na które trudno znaleźć odpowiedź, to, czy zmiany są wystarczająco głębokie, a reorientacja przyniesie zamierzony efekt? Odpowiedź na nie będzie dopiero znana 
w perspektywie następnych 3-5 lat, kiedy to pojawią się pierwsze raporty ewaluacyjne. Jedyne co w chwili obecnej jest wiadome - to kierunki zmian w podejściu do innowacyjności i szczególny nacisk na rozwój innowacyjności MŚP.

\section{Literatura}

Bukowski M., Szpor A., Śniegocki A. 2012 Potencjat i bariery polskiej innowacyjności, Instytut Badań Strukturalnych, Warszawa.

Dokument Rządowy, przyjęty 8 kwietnia 2014 roku pod nazwą Krajowa inteligentna specjalizacja (KIS), Ministerstwo Gospodarki, Warszawa.

Grabowski M., Piasecki B., Rogut A., Sybilska A. 2003 Ustugi wspierajace mikeporzedsiebiorstwa, małe przedsiębiorstwa $i$ samozatrudnionych, GPED, Warszawa.

Dokument elektroniczny, tryb dostępu: [http://www.mf.gov.pl, data wejścia: 05.06.2014].

Dokument elektroniczny, tryb dostępu: [https://www.poig.gov.pl, data wejścia: 08.07.2014].

Innovation Diagnostics in Poland, 2011, Instytut Badań Strukturalnych.

Kapil N., Piatkowski M., Radwan I., Gutierrez J.J. 2013 Poland enterprise innovation support review, The World Bank.

Klonowski D. 2009 Innowacyjność sektora MŚP w Polsce. Rzqdowe programy wsparcia a luka Finansowa, Ernst \& Young, Warszawa.

Komunikat KE COM 2012615 Wniosek. Rozporzqdzenie Parlamentu Europejskiego i Rady ustanawiajace wspólne prappisy dotyczqce Europejskiego Funduszu Rozwoju Regionalnego, Europejskiego Funduszu Społecznego, Funduszu Spójności, Europejskiego Funduszu Rolnego na rzecz. Rozwoju Obszarów Wiejskich oraz Europejskiego Funduszu Morskiego i Rybackiego objetych zakresem wspólnych ram strategicznych oraz ustanawiajace przepisy ogólne dotyczqce Europejskiego Funduszu Rozwoju Regionalnego, Europejskiego Funduszu Społecznego i Funduszu Spójności, oraz uchylajace rozporzqdzenie Rady (WE), nr 1083/2006.

Komunikat Komisji do Parlamentu Europejskiego, Rady, Europejskiego Komitetu EkonomicznoSpotecznego i Komitetu Regionów „Horyzont 2020” - Program Ramowy w zakresie Badań Naukowych i Innowacji, Bruksela, dnia 30.11.2011, KOM(2011) 808, wersja ostateczna.

Konkurencyjna Polska. Jak awansować w swiatowej lidze gospodarczej? 2013, J. Hausner (red.), Fundacja Gospodarki i Administracji Publicznej, Kraków.

Mazurek-Kucharska B., Block A., Wojtczuk-Turek A. 2008 Spoteczne determinanty innowacyjności przedsiębiorstw. Raport z badania, Pentor International Research, Warszawa.

Mechanizmy insznierii finansowej w podnoszeniu efektywności absorpcji środków UE i ich znaczenie w polityce spójności po 2013 roku 2010, Instytut Badań nad Gospodarką Rynkowa, Gdańsk.

Ośrodki innowacji i przedsiębiorczości w Polsce, 2012, A. Bąkowski, M. Mażewska (red.), PARP, Warszawa. 
Ośrodki innowacii i przedsiebiorczości w Polsce 2010, K. B. Matusiak (red.), PARP, Warszawa.

Program Operacyjny Inteligentny Rozwój, 2014-2020 2014, Ministerstwo Infrastruktury i Rozwoju, Warszawa.

Program Rozwoju Przedsiębiorstw do 2020 roku 2014, Program Wykonawczy do Strategii Innowacyjności i Efektywności Gospodarki, Ministerstwo Gospodarki, Warszawa.

Raport o stanie sektora malych $i$ średnich przedsiebiorstw w Polsce w latach 2011-2012 2013, A. Tarnawa, P. Zadura-Lichota (red.), PARP, Warszawa.

Rozporzadzenie Parlamentu Europejskiego $i$ Rady (UE) Nr 1287/2013 z. dnia 11 grudnia 2013 roku ustanawiajace program na rzecz. konkurencyjności przedsiebiorstw oraz matych i średnich przedsiębiorstw (COSME) (2014-2020), Dziennik Urzędowy Unii Europejskiej L 347 z dnia 20 grudnia 2013 roku.

Szymborska-Sutton A. 2014 Zniknie ulga na zakup nowych technologii, w zamian nowe odliczenie, dokument elektroniczny, tryb dostępu: [http://www.forbes.pl/ulgapodatkowa-dla-wydajacych-na-badania-i-rozwoj,artykuly,174817,1,1.html, data wejścia: 05.06.2014]. 